\title{
Beyond Childcare: Changes in the Amount and Types of Parent-Child Time over Three Decades
}

\author{
Dana Wray $^{1}$ \\ Julia Ingenfeld ${ }^{1}$ \\ Melissa A. Milkie ${ }^{1}$ \\ Irene Boeckmann ${ }^{1}$
}

This is the pre-peer reviewed version of the following article:

Wray, D., Ingenfeld, J., Milkie, M. A., \& Boeckman, I. (2021). Beyond Childcare: Changes in the Amount and Types of Parent-Child Time over Three Decades. Canadian Review of Sociology / Revue canadienne de sociologie. doi:10.1111/cars.12356

which has been published in final form at https://doi.org/10.1111/cars.12356. This article may be used for non-commercial purposes in accordance with Wiley Terms and Conditions for Use of Self-Archived Versions.

*This research is supported by the Social Sciences and Humanities Research Council (SSHRC) Insight grant "Time Together and Apart: Clarifying the Family Time Paradox in Canada and the United States.” Melissa A. Milkie, Principal Investigator. Irene Boeckmann, Co-Investigator (Project period 4/19 to 3/23).

${ }^{1}$ Department of Sociology, University of Toronto, 725 Spadina Avenue, Toronto, Ontario, M5S 2J4, Canada. 


\begin{abstract}
Parents' time with children has increased over the past several decades, according to many scholars. Yet, research predominantly focuses on childcare activities, overlooking the majority of time parents spend with children. Using time diaries from the 1986-2015 Canadian General Social Survey, we examine trends in the quantity and distribution of parents' childcare time and total contact time in the company of children, as well as the behavioral or compositional drivers of these trends. Contact time with children increased sharply since the mid-1980s, by 1 hour per day for fathers and 1.5 hours for mothers. This rise was driven not only by childcare activities but also parents' time in housework and mothers' time in leisure with children present. Decomposition analyses indicate that changes in parenting behavior primarily explain these increases in contact time. This study expands knowledge on intensive parenting through a more comprehensive understanding of parents' daily lives with children.
\end{abstract}

\title{
KEYWORDS
}

childcare, fathers, parenting, mothers, time use 


\section{INTRODUCTION}

Has parents' time with children increased over recent decades? We only know part of the answer, because only one form of parent-child time - "childcare" - is typically measured. Parents' childcare time has steadily increased over the past several decades in Canada (Guppy, Sakumoto, and Wilkes 2019; Moyser and Burlock 2018; Wei 2020), the United States (Bianchi, Robinson, and Milkie 2006; Sayer, Bianchi, and Robinson 2004), and in other countries (Craig, Powell, and Smyth 2014; Dotti Sani and Treas 2016). Despite rises in women's participation in the labor market, which sparked fears of deficits in parents' time with children (Bianchi 2000), mothers and fathers have protected their time in childcare. Scholars point to norms of intensive parenting - which call on parents to invest substantial time, energy, and financial resources into children - as one of the main drivers of these trends (Hays 1996; Lareau 2003; Sayer, Bianchi, and Robinson 2004). However, it is less clear whether these steady rises in childcare hold for the total time parents spend with children in the face of countervailing trends such as women's rising employment.

By and large, childcare activities - which include physical care, playing, reading, or supervising

homework - have been at the center of attention of research on parent-child time. The increase in childcare time is often framed as encompassing all time that parents and children spend together, or at least the majority of "quality" time (Hsin and Felfe 2014; Kalil, Ryan, and Corey 2012). However, childcare is only one relatively narrow category of parent-child time. It makes up only about one-third of the total time parents spend in the company of their children and is more central for young children (Bianchi 2000; Fedick, Pacholok, and Gauthier 2005; Folbre et al. 2005). Focusing on childcare alone risks overlooking supervisory care or time when parents are 
engaged in other activities, like housework, but still keep an eye on their children to ensure their well-being (Budig and Folbre 2004; Folbre et al. 2005). A narrow focus on childcare may also miss parents' time with children in leisure activities or mealtimes (Bowen, Elliott, and Brenton 2014; Craig, Powell, and Smyth 2014; Negraia, Augustine, and Prickett 2018). Furthermore, shared time together other than childcare has been shown to be salient for the subjective wellbeing of family members (Flood, Meier, and Musick 2019; Milkie, Wray, and Boeckmann 2020; Musick, Meier, and Flood 2016; Negraia and Augustine 2020). Thus, examining total time expands our understanding of parent-child time and its consequences for family dynamics and well-being.

In contrast to trends in childcare time, it is less clear how the total time parents spend with children has changed over the past several decades. The scarce research on contact time shows cross-national variation in trends: one study finds decreases in parents' contact time in Australia from 1992 to 2006 (Craig, Powell, and Smyth 2014), whereas another shows increases in the U.S. from 1975 through 2000 (Bianchi, Robinson, and Milkie 2006). Beyond the quantity of contact time, we know even less about the types of activities (e.g., leisure, housework) in which parents and children share time. Finally, and most fundamentally, the "why" is also understudied. Is parents' contact time driven by behavioral changes, such as shifts in norms of intensive parenting? Or is contact time primarily driven by compositional changes, i.e. parents' characteristics, such as rising educational attainment and maternal employment?

This study examines how the time mothers and fathers spend with their children has changed from 1986 to 2015 and disentangles the factors that have contributed to this change. Using time 
use data from the Canadian General Social Survey (GSS), a repeated, cross-sectional survey, we trace trends in parents' childcare time and contact time in the company of children. We investigate shifts in the distribution of contact time by presenting the types of activities parents engage in when co-present with their children including, but not limited to, childcare. Finally, we use Blinder-Oaxaca decomposition analyses to assess how behavioral and compositional factors have driven the trends, and whether these factors explain childcare and contact time differently.

We extend previous research on trends in parental time in several ways. First, we broaden the scope of parent-child time beyond childcare activities to investigate trends in the total time parents spend in the company of children. Second, we use Canadian time use data that provides a consistent definition of time "with" children, unlike U.S. data which narrowed the definition to a more bounded operationalization of co-presence in the early 2000s (Allard et al. 2007; Folbre and Yoon 2007). The Canadian data definition captures aspects of parents' supervisory or “on call" care, which can be overlooked when focusing on primary caregiving (Budig and Folbre 2004; Fedick, Pacholok, and Gauthier 2005; Folbre and Yoon 2007). Third, we extend the temporal scope of prior research well into the twenty-first century to examine three decades of change in parental time. This study illuminates a shift in parents' behavior over the past decades, not only in childcare but in all their time in the company of children, and thus expands notions of intensive parenting based on a more comprehensive perspective on parents' daily life with children. 


\section{BACKGROUND}

\section{Childcare Time and Contact Time}

The conceptualization of parents' time with children is an important issue for researchers, policymakers, and the public. Generally, studies using time use data focus on activities defined as childcare, where parents report being engaged with children as a primary activity (Bianchi, Robinson, and Milkie 2006). A particular focus is "developmental" childcare activities - such as playing, reading, helping with homework - which research suggests is high-quality and central to children's development (Altintas 2016; Cha and Park 2020; Hsin and Felfe 2014; Kalil, Ryan, and Cory 2012). Yet, scholars have argued that insufficient attention is paid to parent-child time more broadly (Budig and Folbre 2004; Folbre et al. 2005). Other activities in the company of children are also salient for understanding family life. In fact, these activities represent a much larger portion of time parents and children spend in each other's company than childcare alone, and thus are vital to examine as part of a full understanding of parent-child time.

Whereas childcare focuses on activities such as playing, reading, emotional care, or physical care for children, total contact time captures all time that parents report being in the company of children. Parents might report being with children while doing housework or engaged in their own leisure activity - such as washing the dishes while a child is nearby or watching TV with a child present. Contact time also includes family mealtime, which carries moral weight for parents (Bowen, Elliott, and Brenton 2014; Murcott 2012; Musick and Meier 2012). Furthermore, even if the co-presence of children does not necessarily mean that parents and children interact (Craig 2006), contact time more fully captures time in "on-call," supervisory, or passive care than childcare alone (Budig and Folbre 2004; Craig 2006; Folbre and Yoon 2007). 
The emotional and mental labor of caregiving and parents' responsibility for children may be more difficult to quantify (Doucet 2015). Overall, total contact time best captures the full labor of parents and the capacity of parents to both supervise and interact with children.

Extending the conceptualization of parent-child time beyond childcare to time spent together has bearing on understanding family well-being. Parents report higher subjective well-being in activities when their children are in their company (Musick, Meier, and Flood 2016; Meier et al. 2018; Milkie, Wray, and Boeckmann 2020), including in leisure and housework activities (Flood, Meier, and Musick 2019; Negraia and Augustine 2020) and in meals. Shared mealtime is an important ritual for collective meaning and well-being in families (Musick and Meier 2012). Focusing solely on childcare activities may thus overlook essential sources of parent-child togetherness and well-being.

\section{Trends in Parent-Child Time: Childcare and Contact Time}

Parents have increased their time spent on childcare over the past decades in Canada, the U.S., and similar Western countries (Bianchi 2000; Bianchi, Robinson, and Milkie 2006; Craig, Powell, and Smyth 2014; Dotti Sani and Treas 2016; Guppy, Sakumoto, and Wilkes 2019; Moyser and Burlock 2018; Wei 2020; Sayer, Bianchi, and Robinson 2004). In Canada, parents devoted over three hours per day in 2015 to childcare activities, up from about two hours in 1986 (Guppy, Sakumoto, and Wilkes 2019). Although men's relative contribution to childcare has increased more steeply than mothers' time in childcare, a substantial gender gap persists (Moyser and Burlock 2018; Wei 2020). This steady increase in childcare time has occurred despite countervailing trends such as the growth of dual-earner families in Canada, driven by women's 
rising employment (Guppy and Luongo 2015). In the face of competing demands from paid work, parents have preserved valued time in childcare, often trading off free time or less desirable housework time (Bianchi, Robinson, and Milkie 2006). The increase in childcare time in the face of the 'time squeeze' of work and family demands may also reflect how childcare is valued by parents and how it contributes to parents' subjective well-being (Meier et al. 2018; Musick, Meier, and Flood 2016; Negraia and Augustine 2020).

It is less clear though how the total time parents spend in the company of their children has changed over time, and in what types of activities this time together is concentrated. The few studies that do examine contact time show cross-national variation in trends across different eras. In the U.S., parents' contact time increased from 1975 to 2000: from 21 to 33 weekly hours for married fathers and from 47 to 51 hours for married mothers (Bianchi, Robinson, and Milkie 2006). However, there is little evidence on trends in American parents' contact time with children into the twenty-first century, which may be due to changes in the definition of copresence in U.S. time-use surveys. Starting in 2003, the American Time Use Survey (ATUS) asks respondents about who was "in the room with" or accompanied them during activities (Folbre and Yoon 2007). Earlier U.S. time diaries did not restrict the location (Allard et al. 2007), making analyzing time trends in parent-child togetherness more difficult.

Other studies using time diaries with a broader definition of "who were you with" without a specified location (Folbre and Yoon 2007) find that contact time has declined. In a study examining Canadian teenagers, Zuzanek and Hilbrecht (2018) find that adolescent-parent contact time shrunk from 3.2 to 2 daily hours from 1986 to 2005 . However, teenagers may perceive 
togetherness differently than parents (Milkie, Wray, and Boeckmann 2020), so parental reports - especially regarding younger children - may not align. In Australia, parents' time in the company of children declined by about 2 hours per week between 1992 and 2006 (Craig, Powell, and Smyth 2014). However, these studies do not probe later into the twenty-first century. Overall, this suggests parents' contact time with children may not track dramatic increases in childcare time. Examining trends in total contact time with children also lays the groundwork for assessing how this time is allocated across various activities beyond childcare, and how this distribution has changed over time.

\section{Explaining Trends in Parent-Child Time: Behavioral or Compositional?}

What might explain trends in contact time with children compared to childcare time? Past research on childcare points to behavioral change - the rise of intensive parenting - as the primary driver of increases in childcare time (Craig, Powell, and Smyth 2014; Sayer, Bianchi, and Robinson 2004; Wei 2020). However, we know little about the drivers of changes in contact time. Our study covers a period of social and demographic change in Canada, including rising levels of educational attainment and maternal employment, delayed childbearing, increases in single-parent families, and smaller family sizes. These compositional shifts may have contributed to changes in contact time. At the same time, behavioral change - particularly the increasing salience of intensive parenting - may drive increases in contact time as well.

\section{Behavioral Change: Evidence of Intensifying Parenthood?}

The dramatic increases in parents' childcare time align with shifts in the cultural context of parenthood, particularly the intensification of parenting. Contemporary parenting norms 
emphasize parental engagement with children along with the responsibility for children's development, well-being, and safety (Christopher 2012; Ishizuka 2019; Nelson 2010). This discourse of 'intensive mothering' is particularly salient for women (Hays 1996; Wall 2010). The expectation of significant time and emotional investments in children is also increasingly a part of 'involved fatherhood' (Schoppe-Sullivan and Fagan 2020; Wall and Arnold 2007). These behavioral shifts in 'good parenting' require more time-consuming parenting from both mothers and fathers, and are linked to increasing childcare time (Sayer, Bianchi, and Robinson 2004).

These normative shifts may also lead to parents feeling increased pressure to spend more time with and around their children more generally. Indeed, 47 percent of employed Canadian parents report that they have too little time with children (Milkie, Nomaguchi, and Schieman 2019). As a result, parents may be investing more time in childcare while simultaneously integrating children more widely into their daily lives. As the parental role becomes increasingly child-centered, parents may also feel pressure to supervise their children more often (Nelson 2010). Thus, the rise of intensive parenting may lead to not only increased childcare time but also rising contact time with children.

\section{Compositional Changes: Rising Education, Employment, and Demographic Change}

Education. One key compositional change related to parental time is the growth of postsecondary education. By 2016, over half of Canadians of working age had either college or university qualifications, with just over one-quarter holding a university degree (Statistics Canada 2017b). Childcare time is positively associated with parents' education in Canada, the U.S., and similar Western countries (Dotti Sani and Treas 2006; Kalil, Ryan, and Corey 2012; 
Monna and Gauthier 2008; Schneider, Hastings, and Labriola 2018; Wei 2020). However, educational gradients are less stark in Canada compared to the U.S. (Ramey and Ramey 2010). Thus, the increase in highly-educated Canadian parents may contribute to increased childcare time, but it may play a smaller contributing role than in other contexts.

How rising educational attainment among Canadian parents may impact their contact time with children is unclear. Middle-class parents engage in "concerted cultivation" (Lareau 2003), a style of parenting characterized by deliberate efforts to foster children's development of cognitive and emotional skills, often through leisure and enrichment activities orchestrated by parents. This may result in decreased time together: children might participate in extracurricular activities rather than spending time with parents. On the other hand, as intensive mothering may be particularly pervasive for middle-class mothers (Fox 2006; Wall 2010), more educated parents may prioritize spending more time with their children, leading to increases in contact time. The limited research that explores how educational attainment might be linked to trends in contact time finds no evidence of a relationship (Craig, Powell, and Smyth 2014).

Employment. Another compositional shift is the increase in women's employment in paid work (Bianchi 2000). Canadian women's labor force participation increased from 70 percent in 1986 to 82 percent in 2015 (Statistics Canada 2015a), albeit at a relatively slow pace (Guppy and Luongo 2015). In contrast, men's employment has barely changed and remains high at 91 percent in 2015 (Statistics Canada 2015a). This has led to growth in the proportion of dual-earner families from about 39 to 59 percent (Moyser and Burlock 2018). As time is a finite resource, we would expect that an increase in paid work necessitates a decrease in other activities, such as 
time with children. At the same time, parents who work for pay spend more time in childcare than those in previous cohorts (Bianchi 2000; Bianchi, Robinson, and Milkie 2006). Further, increases in mothers' time in paid work are positively associated with fathers' childcare time (Raley, Bianchi, and Wang 2012), and may also shape father's contact time with children. As such, even as the profile of parents' employment has changed, it may be less relevant for explaining parent-child time than in the past.

Demographic change. Changes in the composition of Canadian families may also be related to changes in parent-child time. Single-parent families have become more common, accounting for 20 percent of families with children under age 16 in 2014, an 11-percentage point increase since the late 1970s (Statistics Canada 2015b). Families are smaller in size, with the modal number of children at two (Beaujot and Muhammad 2006). Parents are older, as delayed childbearing is more common; the mean age of first birth for mothers rose from 25.6 in 1986 to 29.2 in 2015 (Statistics Canada 2014; Provencher et al. 2018). In addition, there was substantial growth in the immigrant population of Canada from 1986 to 2015 (Statistics Canada 2016).

The impact of these demographic changes on parents' contact time or childcare time is not clear, as countervailing forces may be at play. First, the rise in single-parent families may have resulted in decreases in the total parental investment in children (Labriola and Schneider 2019). At the same time, evidence suggests that single mothers do not spend any less time in childcare than married mothers (Pepin, Sayer, and Casper 2018). Second, the number of children in a family is associated with the amount of time parents spend in childcare activities (Sayer, Bianchi, and Robinson 2004), suggesting that shifts to smaller families would lead to decreases in the total 
time parents spend in the company of children. Yet, parents may also invest more time in each child, so changes in average family size over time may not impact time with children. Third, parents who delay childbearing may face competing demands from paid work during prime working years, leading to less time with children (Bianchi and Mattingly 2003). Finally, it is less clear how the rising proportion of immigrant parents may impact parent-child time, given the many different host countries and cultures.

\section{Summary and Research Questions}

In sum, although research documents the rise in childcare time over the past several decades in Canada, the U.S., and similar Western countries (Bianchi et al. 2006; Dotti Sani and Treas 2016; Wei 2020), there is little evidence of trends in how parents and children spend their time together in activities other than childcare. Further, little is known about the behavioral or compositional drivers of trends in parent-child time. This study addresses three research questions:

1. How has parents' contact time with children changed over three decades?

2. What types of activities do parents engage in when in the company of their children? How has this time allocation shifted?

3. To what extent are changes in parents' contact and childcare time driven by compositional versus behavioral changes?

\section{DATA AND METHODS}

\section{Data}

We use data from the Canadian General Social Survey (GSS) on Time Use for the years 1986, 1992, 1998, 2005, 2010, and 2015. The GSS is a repeated cross-sectional survey that randomly 
samples individuals from the non-institutionalized Canadian population aged 15 and older in ten provinces. ${ }^{1}$ The GSS asks one individual per household to recall activities over a 24-hour period on a designated day. Activities were recorded in 5-minute intervals except for 2015, where 10minute intervals were used. Information includes the type of activity, duration, location, and who else was present. The age range of household children varies across years: In 1986 and 1992, no age limits were specified, but from 2005 to 2015, the time diary only asked about the presence of children under 15 years old. To ensure consistency over time in the measurement of co-present children, we limit our sample to mothers and fathers aged 18-64 with at least one household child $^{2}$ under 15 years old. These criteria give us an initial sample of 19,815 parents. After dropping observations with missing values on key variables (949 dropped), the final analytic sample includes 18,866 parents across six waves: 2,913 in 1986, 2,869 in 1992, 2,640 in 1998, 4,341 in 2005, 3,150 in 2010, and 2,953 in 2015.

\section{Measures}

Our expanded measure of parent-child time, contact time with children, represents the total number of minutes ${ }^{3}$ that parents report being "with" at least one household child. The question "Who was with you?" does not specify whether children have to be in the room with the parent, so the measure of co-presence remains broad. Unlike the more narrow definition of "who was in the room with you/who accompanied you" in the ATUS, the GSS may better capture situations

\footnotetext{
${ }^{1}$ In 1986, respondents were interviewed only in November and December; other waves conduct interviews in all months. In 2015, the GSS moved to a new sampling frame and weighting strategy to account for cellular phone usage. Survey weights adjust for a varied response rate, from 80 percent before 2000 to 38 percent in 2015. This decline is similar to other time use surveys in various countries (Statistics Canada 2019).

${ }^{2}$ Household children are defined as birth (biological), adopted, or stepchildren across surveys, but we are unable to distinguish whether foster children are included in all years.

${ }^{3}$ The presence of others was not asked for several activities classified as personal care (e.g., sleep, washing, dressing) - except in the 2015 wave, due to the collapsing of codes for the 'light' time diary. For consistency, we exclude "washing, dressing"; "private prayer, meditation, other informal spiritual activities"; "night sleep/essential sleep"; "naps/lying down"; and "other personal care or private activities."
} 
where the parent feels responsibility for children or supervises them even if they are not in the same room with them (Budig and Folbre 2004). This broader definition was also used in the U.S. through 2000 and is used in other countries currently (Allard et al. 2007; Folbre and Yoon 2007).

We also look at parents' time when children are present in six activities that together add up to our measure of total contact time with children ${ }^{4}$ (Bianchi, Robinson, and Milkie 2006).

Childcare $^{5}$ involves care for children including physical care, playing, teaching, reading, among others. Housework involves cooking, home repairs, cleaning, and shopping. Leisure includes watching TV, playing sports, attending cultural events, and participating in volunteering. Meals include eating meals at home. Shopping/services include grocery shopping and purchasing or obtaining services such as banking, government, or medical. Travel includes any travel to and from activities. ${ }^{6}$ Other activities include market work, education, adult care, care of nonhousehold children, and personal care.

We also include relevant characteristics that might affect parental time with children. The respondent's employment status is measured with a binary variable indicating whether they were employed or not (reference category) in the past week. We measure hours of work by the number of paid work hours reported on the diary day. ${ }^{7}$ Educational attainment is coded as less than high

\footnotetext{
${ }^{4}$ The number of activity codes varies from 96 in 1986 to 264 in 2010, but only 64 in the 2015 'light' time diary. As we use broader activity categories, our measures are consistent across waves.

${ }^{5}$ Statistics Canada notes that derived variables for childcare activities in the 2015 main file are not comparable with 2010 variables (Statistics Canada 2017a:45-6). However, we ensure comparability by using the episode files to construct activities when children under age 15 are present.

${ }^{6}$ Travel cannot be disaggregated based on activity type in 2015. In 1998, activities are only recorded as travel if the respondent is the driver of the car; this may underestimate travel time.

${ }^{7}$ Work hours are measured only as full- or part-time in 1986. 18 percent of respondents with a weekday diary who were employed in the last week report 0 hours of paid work. We test models with a categorical measure of employment but results do not substantively change.
} 
school (reference category), high school diploma, college diploma, and university degree.

Household income is collapsed into quartiles and includes an indicator for missing values to create a harmonized measure across years. Other covariates include the number of household children under age 15 (one, two, or three or more); the age of the youngest child, coded as 0-4 (reference category), 5-9, and 10-14 years old; marital status, coded as married or common-law ${ }^{8}$ (reference category), divorced or widowed or separated, and single; immigrant status (Canadianborn = reference category); and age, which was transformed from 5- or 10-year age groups into years using the midpoints of the original categories. We also control for whether the diary was collected on a weekend or weekday (reference category); and the percentage of diary episodes where the location is reported as "home," to account for potential changes in the time children spend at home over our observation window (Mullan and Chatzitheochari 2019; Twenge 2007).

Table 1 displays the means and proportions of key variables, for mothers and fathers with at least one household child under age 15, in 1986 and 2015 (available for all years in the online appendix, Tables A1 and A2). Given that the time period stretches over thirty years, there are notable changes in the composition of the samples over time in terms of labor market, demographic, and household characteristics. First, the proportion of fathers holding a university degree increased from 17 to 41 percent between 1986 and 2015, and from 12 to 39 percent among mothers. Second, maternal employment participation increased by 20 percentage points from 44 percent in 1986 to 64 percent in 2015. Mothers increased the time they spent on paid work on the diary day by about 41 minutes, whereas fathers decreased their time by about 19 minutes. Third, there are several demographic changes. A sizeable proportion of parents are

\footnotetext{
${ }^{8}$ It is not possible to separately identify common-law until 1998. In 1986, there are no instructions for reporting common-law relationships. In 1992, common-law is included in the category "married."
} 
immigrants, growing from 22 to 34 percent for fathers and 21 to 31 percent for mothers. Delayed childbearing is reflected in the somewhat higher average age of parents in 2015 compared to 1986. The number of household children remains fairly steady, as fertility and family sizes shrunk prior to the late 1980s in Canada (Beaujot and Muhammad 2006). Finally, two-parent households have declined somewhat as well by four percentage points for married or commonlaw.

\section{[INSERT TABLE 1 HERE]}

\section{Analytic Strategy}

To address the first two research questions, we descriptively explore the trends in average contact time with children from 1986 to 2015 for mothers and fathers separately. Furthermore, we examine shifts in the amount and the share of time parents spend in different activities in the company of children over this time period. Analyses are weighted with population weights provided by Statistics Canada.

Second, we conduct an Oaxaca-Blinder decomposition to answer the third research question. We examine how much of the changes in mothers' and fathers' time with children can be attributed to compositional changes (e.g., changes in the composition of parents in terms of educational attainment or labor force participation), and how much may be explained by behavioral changes of parents that are not the direct result of any of the compositional factors included in the analyses. We present separate decomposition models for mothers and fathers that compare the time spent with children in 1986 with 2015, the years at the beginning and end of the observation window to capture the overall change in parent-child time. Formally, analyses are based on the following equation: 


$$
\overline{\mathrm{T}}_{2015}-\overline{\mathrm{T}}_{1986}=\left(\mathrm{X}_{2015}-\mathrm{X}_{1986}\right) * \beta_{2015}+\left(\beta_{2015}-\beta_{1986}\right) * \mathrm{X}_{1986} .
$$

Each decomposition is based on two separate OLS regression models for the years 1986 and 2015. The coefficients from these models are then used to decompose the change in the total time parents report being with household children between 1986 and $2015\left(\bar{T}_{2015}-\overline{\mathrm{T}}_{1986}\right)$ into two parts: The part of the change that can be explained by changes in parental characteristics (compositional effects), and an "unexplained" component. On the right-hand side, the first half of the equation, $\left(\mathrm{X}_{2015}-\mathrm{X}_{1986}\right) * \beta_{2015}$, estimates how much of the change can be accounted for by changes in parents' measured characteristics that affect their time spent with children, such as changes in their educational attainment or their labor force participation. The second half of the equation, $\left(\beta_{2015}-\beta_{1986}\right) * \mathrm{X}_{1986}$, represents the part of the change in parental time with children that is not attributable to changes in parents' characteristics over time. This "unexplained" part of the change can potentially be attributed to the change in the relationship between parental characteristics and their contact time with children, in other words changes in parents' behavior. Such behavioral changes could be driven by social change, such as the intensification of parenting. This latter interpretation, however, has to be taken with caution, as this unexplained part could also reflect changes based on unmeasured parental characteristics.

\section{RESULTS}

\section{Trends in Parent-Child Time}

Figure 1 displays the average daily minutes mothers and fathers spend in contact time - all time in the company of their children - and in childcare activities across the time period from 1986 to 2015. Both childcare and contact time follow relatively similar trends: a slow but steady increase until 2005, when time with children rose sharply. Between 1986 to 2015, mothers increased their contact time with children by 91 daily minutes or about 1.5 daily hours, and fathers 82 minutes 
or about 1.4 hours per day. As mothers spent more time in the company of children at the beginning of this period than fathers, the similar growth means that the gender gap remains fairly consistent over time. The trends in childcare time mirror these patterns: both mothers and fathers increased their time in childcare activities by about 27 minutes each from 1986 to 2015 . Relative to the 1986 levels of childcare, this growth represents a more substantial change for fathers than for mothers.

\section{[INSERT FIGURE 1 HERE]}

Next, we examine how parents' contact time with children is allocated to different kinds of activities and how this distribution has shifted over time. The bars in Figure 2 represent the total daily minutes of mothers' and fathers' time in the company of children in 1986 and 2015 for the six activity types: childcare, housework, leisure, meals, travel and other. In addition to increased parental time spent on childcare, the most noteworthy change over this period is the rise in parents' time spent in housework with children present. These two activity types are the biggest contributor to the growth in contact time for both mothers and fathers. From 1986 to 2015, both fathers and mothers increased their time in childcare by around 27 daily minutes and time in housework with children present by around 31 daily minutes. By the end of our observation period in 2015, fathers and mothers spent one to almost two hours per day, respectively, in housework while in the company of children. In contrast, the time having meals with children has declined, with fathers losing 4 minutes and mothers 12 minutes per day over time.

\section{[INSERT FIGURE 2 HERE]}

To further clarify how parents' contact time is distributed across various activities, Figure 3 presents the share of total contact time spent across activities (share = daily minutes in selected activity / daily minutes in contact time with children) in 1986 and 2015 by parents' gender. 
Crucially, the figure shows that parents' time in childcare does not represent the largest share of their contact time with children. For mothers, childcare activities represent about a quarter of their contact time, almost unchanged since 1986. Fathers only spent one-fifth of their contact time with children on childcare activities in 2015, up from 15 percent in 1986.

In addition, as the amount of contact time has grown for mothers and fathers, the distribution of this time across activities has shifted over the past three decades. This is particularly true for fathers: housework and childcare have each become greater shares of fathers' time with children, rising by 5 and 7 percentage points respectively, while leisure has shrunk from 41 to 33 percent. It is important to note that the absolute time fathers spend in leisure activities still went up from 1986 to 2015, but they increased their time with children more dramatically in other activities. Finally, mealtimes stand out as the only activity that has decreased in terms of the number of minutes for both mothers and fathers, as well as the share of total contact time, dropping by 7 and 8 percentage points, respectively.

\section{[INSERT FIGURE 3 HERE]}

With these changes, the composition of mothers' and fathers' time across activities has become somewhat more similar over time. By 2015, mothers and fathers both spent about three quarters of their time with children in the three main activities: childcare, housework, and leisure. However, key gender differences remain. In addition to spending almost two daily hours less in the presence of children, fathers continue to spend a larger share of contact time in leisure activities (33 percent) than mothers. In contrast, mothers' activities with children present consist of about 25 percent in each of childcare, housework, and leisure. 


\section{Decomposing Behavioral and Compositional Change}

Tables 2 and 3 show the decomposition results ${ }^{9}$ for total contact time spent with children and time spent in childcare for mothers (Table 2) and fathers (Table 3), using characteristics from 2015 with coefficients from 1986. The decomposition allows us to disentangle how much of the change in parental time between 1986 and 2015 is driven by compositional changes, and how much of the change remains unexplained - and is potentially driven by parents' behavioral changes due to social change.

\section{[INSERT TABLE 2 HERE]}

Between 1986 and 2015 mothers' total time with children increased by about 91 daily minutes - from 338 to 429 minutes per day (Table 2). Mothers' childcare time spent increased from about 80 to 108 daily minutes in the same timeframe, a total increase of almost half an hour per day. The decomposition results indicate that for mothers, the increase in time spent with children and time spent in childcare cannot be explained by changes in mothers' characteristics; instead, it is driven by behavioral changes. In fact, compositional changes among mothers have a dampening effect: If mothers in 2015 had the same characteristics as mothers had in 1986, they would have spent even more time in the company of children - about 13 minutes more contact time, including about 7 minutes more in childcare activities.

More specifically, if mothers in 2015 were employed at the same rate as mothers in 1986, they would have spent roughly 27 minutes per day more with their children and would do about 11 minutes more childcare, all else equal. Similarly, if mothers in 2015 had the same average age as mothers in 1986, they would have spent about 14 minutes more with their children and about 5

\footnotetext{
${ }^{9}$ OLS models underlying the decomposition analyses are available in the online appendix (Table A3 for mothers, Table A4 for fathers).
} 
minutes more in childcare. Mothers' increased educational attainment, on the other hand, accounts for part of their increased time spent with children (about 31 minutes) and increased time in childcare activities (about 9 minutes). Changes in other demographic characteristics, such as in the number of children, marital status or immigrant status, have not substantially contributed to changes in mothers' contact or childcare time.

\section{[INSERT TABLE 3 HERE]}

Similar to mothers, fathers have increased their total time spent with children substantially by 82 daily minutes - from 226 minutes in 1986 to 308 minutes in 2015 (Table 3). Their time spent in childcare increased by 26 daily minutes, from 35 minutes in 1986 to 61 minutes in 2015 . As for mothers, behavioral changes contribute to the majority of the increase in fathers' contact (88 percent) and childcare time (79 percent). However, in contrast to mothers, changes in fathers' characteristics over time (compositional changes) account for some of the increases in contact time and childcare time. In particular, fathers' reduced work hours account for about 9 minutes of the increase in contact time, and changes in fathers' educational attainment account for about 7 minutes of their increased time in childcare. Similar to mothers, demographic changes have not contributed to substantially to changes in time spent with children or time spent in childcare - except the increased prevalence of fathers born outside of Canada, which has a slight dampening effect on paternal time with children. In all, behavioral changes are central to explaining why parents increased their time with children over recent decades.

\section{DISCUSSION}

This study examines trends in childcare and contact time in the company of children over three decades in Canada. The findings indicate that time in childcare and in contact time has increased 
in parallel since 1986 for both fathers and mothers, with a sharper rise in the 2000s. From 1986 to 2015 , mothers' contact time with children grew by 1.5 daily hours and fathers' contact time by one hour. Both mothers' and fathers' childcare time rose by about half an hour a day, which only accounts for about one third of the increase in contact time for mothers, and about half of the increase for fathers. This finding underscores the importance of looking beyond childcare activities to a wider spectrum of parents' activities in the company of children to better understand contemporary parenthood. Decomposing the trends in childcare and contact time points to behavioral change as the primary driver of increases in time with children for mothers and fathers, even in the face of countervailing effects such as rises in maternal employment.

Our findings on parents' contact time extend the few studies that explore how this more comprehensive measure of parent-child time has changed over a period of demographic shifts and behavioral transformation in parenthood. Increases in contact time over the past few decades for Canadian parents align with findings from the U.S. where parents increased their contact time with children from 1975 until 2000 (Bianchi, Robinson, and Milkie 2006). However, the changing definitions of co-presence in the ATUS make the examination of U.S. trends beyond the early 2000s less reliable (Allard et al. 2007; Folbre and Yoon 2007). Our observation window extends into the twenty-first century using a consistent operationalization of contact time. Moreover, contrasting trends in at least one other social context suggest that increases in contact time recorded in North America are not universal. Australian parents' contact time decreased from 1992 to 2006 (Craig, Powell, and Smyth 2014). Comparative research on trends in contact time with children is needed to uncover and understand cross-national differences. 
The full experiences of parents' time with children more broadly should be an important priority for scholars to get a more complete picture of changes in family life and well-being. Past scholarship suggests that time in the company of children is associated with higher subjective well-being for parents (Musick, Meier, and Flood 2016), although this may vary depending on parenting stage (Negraia and Augustine 2020) or the presence of others such as a partner (Dunatchik and Speight 2020). There is also a need for future research on how more time together impacts well-being from the perspective of children as well (Milkie, Wray, and Boeckmann 2020). Because the time diaries in the GSS come from one respondent per household, we cannot explore intra-household dynamics. Future research using diaries from multiple household members, or using novel methods or measures such as synthetic couples (Labriola and Schneider 2019; Vinopal and Gershenson 2017), could shed light on different family members' perspectives. Furthermore, we argue that compared to childcare measures alone, contact time is more likely to capture parenting responsibilities more broadly. At the same time, contact time only measures whether parents reported a child being "with" them, a limitation of time diary data. It cannot capture the quality or intensity of interaction (Folbre and Yoon 2007) and misses the complexity of parents' responsibility and mental labor (Doucet 2015). Qualitative data could further elucidate the nature of time spent in the company of children.

Beyond the quantity of contact time, we show that the types of activities that make up Canadian parents' time with children have also shifted over the past three decades. Previous studies focus on rises in childcare time, particularly developmental childcare activities (Altintas 2016; Cha and Park 2020; Kalil et al. 2012). Yet, we find that a significant part of spending more time together 
seems to be driven by increased time in housework activities when children are present - a novel finding. Strikingly, these changes in housework time with children do not align with general trends in housework. In Canada and the U.S., men have increased the time they spend on housework, but women's housework time decreased over this time period (Bianchi et al. 2012; Guppy, Sakumoto, and Wilkes 2019). Housework thus may have become a family activity of sorts, though exactly what this time together encompasses is unclear. Although the GSS cannot capture whether activities are done "for" someone else, some of this time may be in the service of children - e.g., cooking healthy meals for the family when children are nearby (Beagan et al. 2008). Further investigation into parent-child interaction in housework activities is needed to examine this time together.

Exploring the distribution of parents' contact time across activities also reveals that Canadian parents spend less time - both in daily minutes and the relative share of time together - in meals with their children than in the past. Previous research points to declines in shared family mealtimes cross-nationally across this time period (Mestdag and Vandeweyer 2005). Family mealtime holds a particular cultural weight as an important setting for collective meaning and family well-being; decreasing time in meals could be linked to less actual or perceived quality contact time (Bowen, Elliott, and Brenton 2014; Murcott 2012; Musick and Meier 2012). At the same time, mealtimes are not the only activities associated with increased well-being. Time together in leisure and housework is linked to higher reported subjective well-being (Flood, Musick, and Meier 2019; Negraia and Augustine 2020). It is possible that quality family time takes place in these overlooked activities. These activities may represent new or greater sites of 
family connection compared to the routine family meal. These findings point to a need for a closer examination of parent-child time across a wider range of activities.

Finally, we find that the dramatic increases in contact time and childcare time are primarily driven by behavioral rather than compositional factors. Compositional changes explain a relatively small portion for fathers, and for mothers they play a negligible role - even suggesting a dampening of positive trends. The centrality of behavioral change suggests that the rise of intensive parenting is not limited only to childcare activities (e.g., Sayer, Bianchi, and Robinson 2004; Wei 2020) or those considered developmentally beneficial like reading (Kalil, Ryan, and Corey 2012). Instead, intensive parenting may have led to an increased integration of children in parents' daily lives more generally. This may also be evidence of the pressure on parents to supervise children or spend time with them (Bianchi, Robinson, and Milkie 2006; Ishizuka 2019; Nelson 2010) or that parents simply want more time with children (Milkie, Nomaguchi, and Schieman 2019). This finding indicates the need to incorporate more comprehensive measures of parent-child time to fully understand intensive parenting behaviors.

There may be other behavioral explanations for increased parenting time that do not align with intensive parenting forces. Recent research argues that increased technology use for parents and children (Goode et al. 2020; Twenge 2007; Zuzanek and Hilbrecht 2018) has led to more time spent at home. Increased contact time could be partly an artifact of this shift to home. In the UK, Mullan and Chatzitheochari (2019) use reports from parents and children ages 8 to 16 to show increases in time "alone together," where parents and children are at home in the same location but do not report co-presence. Although the GSS cannot provide children's reports, we account 
for the proportion of parent-child time together at home in our models and find little change. How technology use might impact perceptions and meanings of time together should be investigated further.

Overall, this study pushes scholars to consider parents' time with their children present beyond the narrow scope of childcare - which is limited to a few activities and is more central to contact with young children. Broadening the scope allows for a comprehensive assessment of how much of parents' daily lives include their children, and how this has shifted over a period of demographic and normative change. Children are more incorporated into parents' lives in recent decades - including in mundane activities like when parents do housework - revealing a new shape of intensive parenting. Ultimately, this rise in parent-child time likely has profound implications for family dynamics and well-being in the twenty-first century. 


\section{REFERENCES}

Allard, M. D., S. Bianchi, J. Stewart, and V. R. Wight. 2007. "Comparing Childcare Measures in the ATUS and Earlier Time-Diary Studies.” Monthly Labor Review 130(5):27-36.

Altintas, E. 2016. "The Widening Education Gap in Developmental Child Care Activities in the United States, 1965-2013." Journal of Marriage and Family 78(1):26-42.

Beagan, B., G. E. Chapman, A. D'Sylva, and B. R. Bassett. 2008. “'It's just easier for me to do it': Rationalizing the family division of foodwork." Sociology 42(4):653-671.

Beaujot, R., and A. Muhammad. 2006. "Transformed Families and the Basis for Childrearing." In Canada's Changing Families: Implications for Individuals and Society, ed. Z. R. Ravanera and K. McQuillan, 15-48. Toronto, Canada: University of Toronto Press.

Bianchi, S. M. 2000. "Maternal Employment and Time with Children: Dramatic Change or Surprising Continuity?" Demography 37(4):401-414.

Bianchi, S. M., and M. J. Mattingly. 2003. "Time, Work, and Family in the United States.” Advances in Life Course Research 8:95-118.

Bianchi, S. M., J. P. Robinson, and M. A. Milkie. 2006. Changing Rhythms of American Family Life. New York, NY: Russell Sage Foundation.

Bowen, S., S. Elliott, and J. Brenton. 2014. “The Joy of Cooking?” Contexts 13(3):20-25.

Budig, M. J., and N. Folbre. 2004. "Activity, Proximity, or Responsibility? Measuring Parental Childcare Time." In Family Time: The Social Organization of Care, ed. M. Bittman and N. Folbre, 51-68. London: Routledge.

Cha, Y., and H. Park. 2020. "Converging Educational Differences in Parents' Time Use in Developmental Child Care." Journal of Marriage and Family.

Christopher, K. 2012. "Extensive Mothering: Employed Mothers' Constructions of the Good Mother." Gender \& Society 26(1):73-96.

Craig, L. 2006. "Does Father Care Mean Fathers Share?: A Comparison of how Mothers and Fathers in Intact Families Spend Time with Children." Gender and Society 20(2):259281.

Craig, L., A. Powell, and C. Smyth. 2014. "Towards Intensive Parenting? Changes in the Composition and Determinants of Mothers' and Fathers' Time with Children 19922006." The British Journal of Sociology 65(3):555-579.

Dotti Sani, G. M., and J. Treas. 2016. "Educational Gradients in Parents' Child-Care Time Across Countries, 1965-2012." Journal of Marriage and Family 78(4):1083-1096. 
Doucet, A. 2015. "Parental Responsibilities: Dilemmas of Measurement and Gender Equality." Journal of Marriage and Family 77(1):224-242.

Dunatchik, A., and S. Speight. 2020. "Re-examining How Partner Co-presence and Multitasking Affect Parents' Enjoyment of Childcare and Housework." Sociological Science 7:268290.

Fedick, C. B., S. Pacholok, and A. H. Gauthier. 2005. "Methodological Issues in the Estimation of Parental Time - Analysis of Measures in a Canadian Time-Use Survey." electronic International Journal of Time Use Research 2(1):67-87.

Flood, S., A. Meier, and K. Musick. 2019. "Reassessing Parents' Leisure Quality with Direct Measures of Well-Being: Do Children Detract From Parents' Down Time?” Journal of Marriage and Family.

Folbre, N., and J. Yoon. 2007. "What is Child Care? Lessons from Time-Use Surveys of Major English-Speaking Countries." Review of Economics of the Household 5(3):223-248.

Fox, B. 2006. 'Motherhood as a Class Act: The Many Ways in Which 'Intensive Mothering' is Entangled with Social Class.” In Social Reproduction, 231-262. Montreal, Canada: McGill-Queen's Press.

Goode, J. A., P. Fomby, S. Mollborn, and A. Limburg. 2020. “Children's Technology Time in Two US Cohorts.” Child Indicators Research 13(3):1107-1132.

Guppy, N., and N. Luongo. 2015. "The Rise and Stall of Canada’s Gender-Equity Revolution." Canadian Review of Sociology 52(3):241-265.

Guppy, N., L. Sakumoto, and R. Wilkes. 2019. "Social Change and the Gendered Division of Household Labor in Canada." Canadian Review of Sociology 56(2):178-203.

Hays, S. 1996. The Cultural Contradictions of Motherhood. New Haven, CT: Yale University Press.

Hsin, A., and C. Felfe. 2014. "When Does Time Matter? Maternal Employment, Children's Time With Parents, and Child Development.” Demography 51(5):1867-1894.

Ishizuka, P. 2019. "Social Class, Gender, and Contemporary Parenting Standards in the United States: Evidence from a National Survey Experiment." Social Forces 98(1):31-58.

Kalil, A., R. Ryan, and M. Corey. 2012. "Diverging Destinies: Maternal Education and the Developmental Gradient in Time With Children.” Demography 49(4):1361-1383.

Labriola, J., and D. Schneider. 2019. "Determinants of Class Inequality in Parental Childcare Time: Evidence from Synthetic Couples in the ATUS.” January 23. https://doi.org/10.31235/osf.io/xe3kc 
Lareau, A. 2003. Unequal Childhoods: Class, Race and Family Life. Berkeley, CA: University of California Press.

Meier, A., K. Musick, J. Fischer, and S. Flood. 2018. "Mothers' and Fathers' Well-Being in Parenting Across the Arch of Child Development." Journal of Marriage and Family 80(4):992-1004.

Mestdag, I., and J. Vandeweyer. 2005. "Where Has Family Time Gone? in Search of Joint Family Activities and the Role of the Family Meal in 1966 and 1999." Journal of Family History 30(3):304-323.

Milkie, M. A., K. Nomaguchi, and S. Schieman. 2019. "Time Deficits with Children: The Link to Parents' Mental and Physical Health.” Society and Mental Health 9(3):277-295.

Milkie, M., Wray, D., and Boeckmann, I. 2020. "Creating Versus Negating Togetherness: Perceptual and Emotional Differences in Parent-Teenager Reported Time.” May 9. https://doi.org/10.31235/osf.io/4vp57

Monna, B., and A. H. Gauthier. 2008. "A Review of the Literature on the Social and Economic Determinants of Parental Time." Journal of Family and Economic Issues 29(4):634-653.

Moyser, M., and Burlock, A. 2018. "Time Use: Total Work Burden, Unpaid Work, and Leisure." Women in Canada: A Gender-based Statistical Report. Statistics Canada Catalogue no. 89503-X.

Mullan, K., and S. Chatzitheochari. 2019. "Changing Times Together? A Time-Diary Analysis of Family Time in the Digital Age in the United Kingdom." Journal of Marriage and Family 81(4):795-811.

Murcott, A. 2012. "Lamenting the 'Decline of the Family Meal' as a Moral Panic? Methodological Reflections." Recherches Sociologiques et Anthropologiques 43:97-118.

Musick, K., and A. Meier. 2012. "Assessing Causality and Persistence in Associations Between Family Dinners and Adolescent Well-Being." Journal of Marriage and Family 74(3):476-493.

Musick, K., A. Meier, and S. Flood. 2016. "How Parents Fare: Mothers' and Fathers' Subjective Well-Being in Time with Children." American Sociological Review 81(5):1069-1095.

Negraia, D., and J. M. Augustine. 2020. "Unpacking the Parenting Well-Being Gap: the Role of Dynamic Features of Daily Life across Broader Social Contexts." Social Psychology Quarterly.

Negraia, D. V., J. E. Yavorsky, and D. Dukhovnov. 2019. “Mothers' and fathers' well-being while parenting: does the gender composition of children matter?" 49. MPIDR Working Paper. 
Nelson, M. K. 2010. Parenting Out of Control: Anxious Parents in Uncertain Times. New York: NYU Press.

Pepin, J. R., L. C. Sayer, and L. M. Casper. 2018. "Marital Status and Mothers' Time Use: Childcare, Housework, Leisure, and Sleep." Demography 55:107-133.

Provencher, C., Milan, A., Hallman, S., D’Aoust, C. 2018. "Fertility: Overview, 2012 to 2016. Report on the Demographic Situation in Canada." June 5. Statistics Canada catalogue no. 91-209-X.

Raley, S., S. M. Bianchi, and W. Wang. 2012. "When Do Fathers Care? Mothers' Economic Contribution and Fathers' Involvement in Child Care." American Journal of Sociology 117(5):1422-1459.

Ramey, G., and V. A. Ramey. 2010. “The Rug Rat Race.” Brookings Papers on Economic Activity 2010(1). Brookings Papers on Economic Activity:129-176.

Sayer, L. C., S. M. Bianchi, and J. P. Robinson. 2004. "Are Parents Investing Less in Children? Trends in Mothers' and Fathers' Time with Children." American Journal of Sociology $110(1): 1-43$.

Schneider, D., O. P. Hastings, and J. LaBriola. 2018. "Income Inequality and Class Divides in Parental Investments." American Sociological Review 83(3):475-507.

Schoppe-Sullivan, S. J., and J. Fagan. 2020. "The Evolution of Fathering Research in the 21st Century: Persistent Challenges, New Directions." Journal of Marriage and Family 82(1):175-197.

Statistics Canada. 2014. "Fertility: Fewer Children, Older Moms." Canadian Megatrends. November 13. Statistics Canada catalogue no. 11-630-X. Retrieved July 10, 2020 from: https://www150.statcan.gc.ca/n1/pub/11-630-x/11-630-x2014002-eng.htm

Statistics Canada. 2015a. "The Surge of Women in the Workforce." Canadian Megatrends. December 17. Statistics Canada catalogue no. 11-630-X. Retrieved June 23, 2020 from: https://www150.statcan.gc.ca/n1/pub/11-630-x/11-630-x2015009-eng.htm.

Statistics Canada. 2015b. "Lone-Parent Families." Insights on Canadian Society. Statistics Canada catalogue no. 75-006-X. Retrieved July 8, 2020 from: https://www150.statcan.gc.ca/n1/pub/75-006-x/2015001/article/14202/parent-eng.htm.

Statistics Canada. 2016. "150 Years of Immigration in Canada." Canadian Megatrends. June 29. Statistics Canada catalogue no. 11-630-X. Retrieved July 9, 2020, from: https://www150.statcan.gc.ca/n1/pub/75-006-x/2015001/article/14202/parent-eng.htm 
Statistics Canada. 2017a. General Social Survey, 2015. Cycle 29: Time Use. Public Use Microdata File Documentation and User's Guide. Statistics Canada catalogue no. 89M0034X, released October 2017.

Statistics Canada. 2017b. Education in Canada: Key Results From the 2016 Census. The Daily. November 19. Statistics Canada catalogue no. 11-001-X. Retrieved June 23, 2020 from: https://www150.statcan.gc.ca/n1/en/daily-quotidien/171129/dq171129aeng.pdf?st=ID3mv97o.

Statistics Canada. 2019. General Social Survey: An Overview, 2019. Catalogue no. 89F0115X2019001, released February 20. Retrieved June 20, 2020 from: https://www150.statcan.gc.ca/n1/pub/89f0115x/89f0115x2019001-eng.htm.

Twenge, J. M. 2017. IGen: Why Today's Super-Connected Kids Are Growing Up Less Rebellious, More Tolerant, Less Happy--and Completely Unprepared for Adulthood (and What That Means for the Rest of Us). New York: Atria Books.

Wall, G. 2010. “Mothers' Experiences With Intensive Parenting and Brain Development Discourse." Women's Studies International Forum 33(3):253-263.

Wall, G., and S. Arnold. 2007. "How Involved Is Involved Fathering?: An Exploration of the Contemporary Culture of Fatherhood." Gender and Society 21(4):508-527.

Wei, L. 2020. "Trends in Parental Time Allocated to Child Care: Evidence from Canada, 19862010." Canadian Public Policy 46(2):236-252.

Zuzanek, J., and M. Hilbrecht. 2018. "Do Parents Matter? Teens' Time Use, Academic Performance and Well-Being." Enfances Familles Générations 29:0-28. 
TABLES

Table 1: Means and Proportions for Key Variables, by Sex and Year

\begin{tabular}{|c|c|c|c|c|}
\hline & \multicolumn{2}{|c|}{ Fathers } & \multicolumn{2}{|c|}{ Mothers } \\
\hline & 1986 & 2015 & 1986 & 2015 \\
\hline$N$ & 1,206 & 1,278 & 1,707 & 1,675 \\
\hline Employed & 0.85 & 0.89 & 0.44 & 0.64 \\
\hline Work hours on diary day & 5.86 & 5.55 & 2.71 & 3.40 \\
\hline \multicolumn{5}{|l|}{ Educational attainment } \\
\hline Less than high school & 0.32 & 0.05 & 0.29 & 0.05 \\
\hline High school diploma & 0.35 & 0.16 & 0.42 & 0.14 \\
\hline College diploma & 0.16 & 0.38 & 0.17 & 0.43 \\
\hline University Degree & 0.17 & 0.41 & 0.12 & 0.39 \\
\hline \multicolumn{5}{|l|}{ Household income } \\
\hline First quartile & 0.07 & 0.16 & 0.13 & 0.24 \\
\hline Second quartile & 0.22 & 0.27 & 0.27 & 0.26 \\
\hline Third quartile & 0.49 & 0.26 & 0.40 & 0.23 \\
\hline Fourth quartile & 0.11 & 0.31 & 0.10 & 0.27 \\
\hline Missing & 0.11 & 0.00 & 0.10 & 0.00 \\
\hline Age & 36.47 & 40.86 & 34.25 & 38.42 \\
\hline Immigrant status & 0.22 & 0.34 & 0.21 & 0.31 \\
\hline \multicolumn{5}{|l|}{ Marital status } \\
\hline Married/Common law & 0.98 & 0.96 & 0.88 & 0.84 \\
\hline Widowed/Separated/Divorced & 0.01 & 0.03 & 0.08 & 0.09 \\
\hline Single & 0.01 & 0.01 & 0.05 & 0.08 \\
\hline \multicolumn{5}{|l|}{ Number of household children } \\
\hline One child & 0.39 & 0.41 & 0.46 & 0.47 \\
\hline Two children & 0.40 & 0.44 & 0.39 & 0.39 \\
\hline Three or more children & 0.21 & 0.15 & 0.15 & 0.15 \\
\hline \multicolumn{5}{|l|}{ Age of youngest household child } \\
\hline $0-4$ years & 0.47 & 0.45 & 0.44 & 0.44 \\
\hline $5-9$ years & 0.30 & 0.30 & 0.30 & 0.27 \\
\hline $10-14$ years & 0.23 & 0.25 & 0.26 & 0.29 \\
\hline Quebec & 0.20 & 0.24 & 0.20 & 0.24 \\
\hline Number of activities & 4.10 & 6.27 & 8.47 & 9.12 \\
\hline$\%$ of activities with kids at home & 0.68 & 0.71 & 0.73 & 0.72 \\
\hline Weekend diary & 0.21 & 0.30 & 0.24 & 0.28 \\
\hline
\end{tabular}

Note: 1986 and 2015 GSS. Total N=5,866. All means weighted with Statistics Canada population weights. 
Table 2: Decomposition of Mothers' Contact Time with Children and Childcare Time, 1986 and 2015

\begin{tabular}{|c|c|c|c|}
\hline & Coef. & SE & P-value \\
\hline \multicolumn{4}{|l|}{ Contact Time with Children } \\
\hline Predicted Daily Minutes (2015) & 429.23 & 9.04 & 0.00 \\
\hline Predicted Daily Minutes (1986) & 338.41 & 6.90 & 0.00 \\
\hline Total Change (Daily Minutes) & 90.81 & 11.37 & 0.00 \\
\hline Endowment Effects (Change due to Characteristics) & -13.04 & 15.01 & 0.39 \\
\hline Change due to Coefficients (Social Change) & 103.85 & 15.01 & 0.00 \\
\hline \multicolumn{4}{|l|}{ Explained } \\
\hline Employment & -26.71 & 7.14 & 0.00 \\
\hline Education & 31.47 & 10.97 & 0.00 \\
\hline Income & 4.23 & 3.26 & 0.19 \\
\hline Age & -14.07 & 5.20 & 0.01 \\
\hline Number of Children & -0.26 & 0.66 & 0.70 \\
\hline Marital Status & -1.69 & 1.04 & 0.10 \\
\hline Immigrant Status & -2.97 & 1.72 & 0.08 \\
\hline \multicolumn{4}{|l|}{ Childcare Time } \\
\hline Predicted Daily Minutes (2015) & 107.89 & 4.73 & 0.00 \\
\hline Predicted Daily Minutes (1986) & 79.75 & 3.09 & 0.00 \\
\hline Total Change (Daily Minutes) & 28.14 & 5.65 & 0.00 \\
\hline Endowment Effects (Change due to Characteristics) & -7.14 & 7.07 & 0.31 \\
\hline Change due to Coefficients (Social Change) & 35.29 & 7.77 & 0.00 \\
\hline \multicolumn{4}{|l|}{ Explained } \\
\hline Employment & -11.13 & 2.66 & 0.00 \\
\hline Education & 9.47 & 5.42 & 0.08 \\
\hline Income & 3.98 & 2.22 & 0.07 \\
\hline Age & -4.70 & 2.31 & 0.04 \\
\hline Number of Children & -0.20 & 0.51 & 0.69 \\
\hline Marital Status & 0.22 & 0.45 & 0.63 \\
\hline Immigrant Status & -0.37 & 0.87 & 0.67 \\
\hline
\end{tabular}

Note: 1986 and 2015 GSS. Total $N=3,382$. Models also control for: age of youngest child, whether diary day is a weekend, region of residence, percent of activities with children at home. 
Table 3: Decomposition of Fathers' Contact Time with Children and Childcare Time, 1986 and 2015

\begin{tabular}{|c|c|c|c|}
\hline & Coef. & SE & P-value \\
\hline \multicolumn{4}{|l|}{ Contact Time with Children } \\
\hline Predicted Daily Minutes (2015) & 308.22 & 8.91 & 0.00 \\
\hline Predicted Daily Minutes (1986) & 226.48 & 8.84 & 0.00 \\
\hline Total Change (Daily Minutes) & 81.74 & 12.55 & 0.00 \\
\hline Endowment Effects (Change due to Characteristics) & 10.13 & 14.95 & 0.50 \\
\hline Change due to Coefficients (Social Change) & 71.61 & 17.40 & 0.00 \\
\hline \multicolumn{4}{|l|}{ Explained } \\
\hline Employment & 9.26 & 7.04 & 0.19 \\
\hline Education & -2.76 & 10.82 & 0.80 \\
\hline Income & 1.00 & 4.35 & 0.82 \\
\hline Age & -0.56 & 5.07 & 0.91 \\
\hline Number of Children & -1.37 & 1.34 & 0.31 \\
\hline Marital Status & 0.60 & 0.61 & 0.33 \\
\hline Immigrant Status & -4.07 & 2.29 & 0.07 \\
\hline \multicolumn{4}{|l|}{ Childcare Time } \\
\hline Predicted Daily Minutes (2015) & 61.28 & 3.22 & 0.00 \\
\hline Predicted Daily Minutes (1986) & 34.90 & 2.93 & 0.00 \\
\hline Total Change (Daily Minutes) & 26.38 & 4.35 & 0.00 \\
\hline Endowment Effects (Change due to Characteristics) & 5.59 & 5.25 & 0.29 \\
\hline Change due to Coefficients (Social Change) & 20.79 & 6.20 & 0.00 \\
\hline \multicolumn{4}{|l|}{ Explained } \\
\hline Employment & 0.14 & 1.32 & 0.91 \\
\hline Education & 7.18 & 3.73 & 0.05 \\
\hline Income & -0.78 & 1.67 & 0.64 \\
\hline Age & -0.03 & 2.11 & 0.99 \\
\hline Number of Children & 0.56 & 0.54 & 0.30 \\
\hline Marital Status & 0.41 & 0.35 & 0.24 \\
\hline Immigrant Status & -1.17 & 0.84 & 0.16 \\
\hline
\end{tabular}

Note: 1986 and 2015 GSS. Total $N=2,484$. Models also control for: age of youngest child, whether diary day is a weekend, region of residence, percent of activities with children at home. 


\section{FIGURES}

Figure 1: Mean Daily Minutes in Total Contact Time and Childcare by Parent's Gender and Year

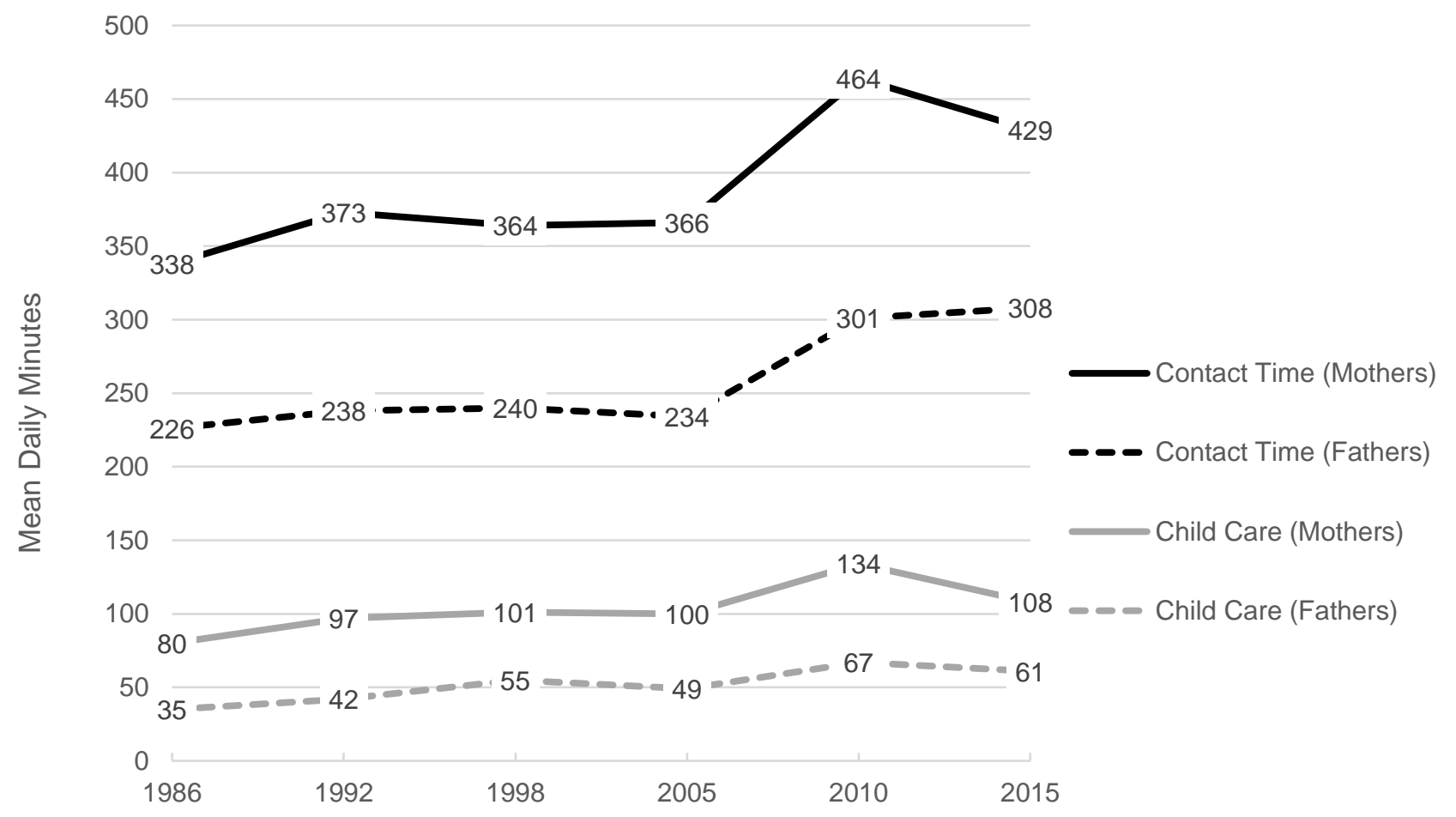

Note: 1986, 1992, 1998, 2005, 2010, 2015 GSS. Total N=18,866. All means weighted with Statistics Canada population weights. 
Figure 2: Mean Daily Minutes in Different Activities with Children by Parents' Gender and Year

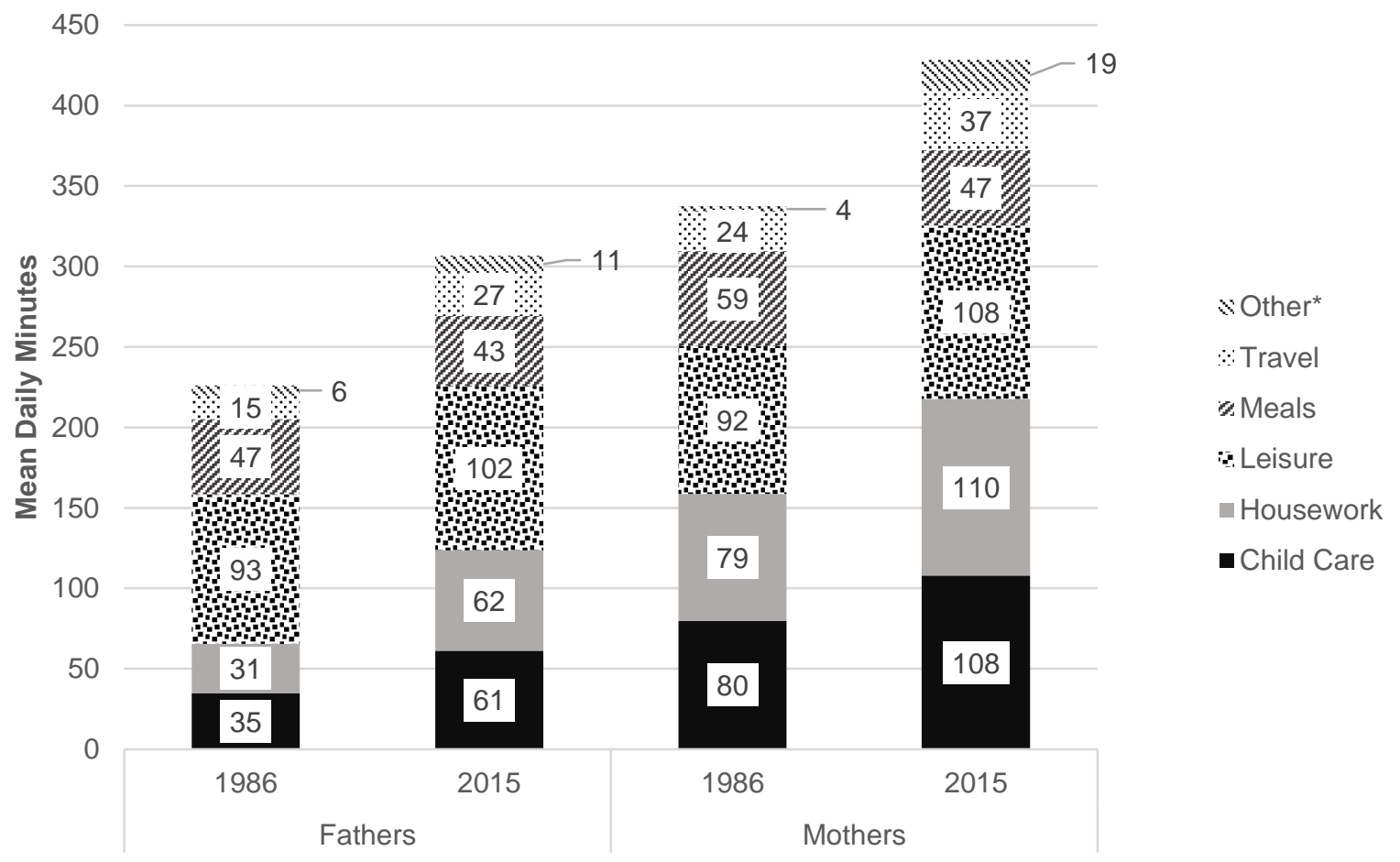

Note: 1986 and 2015 GSS. Total N=5,866. All means weighted with Statistics Canada population weights. * "Other" activities include market work, education, personal care, adult care, and care for nonhousehold children. 
Figure 3: Share (\%) of Contact Time with Children in Different Activities by Parents' Gender and Year

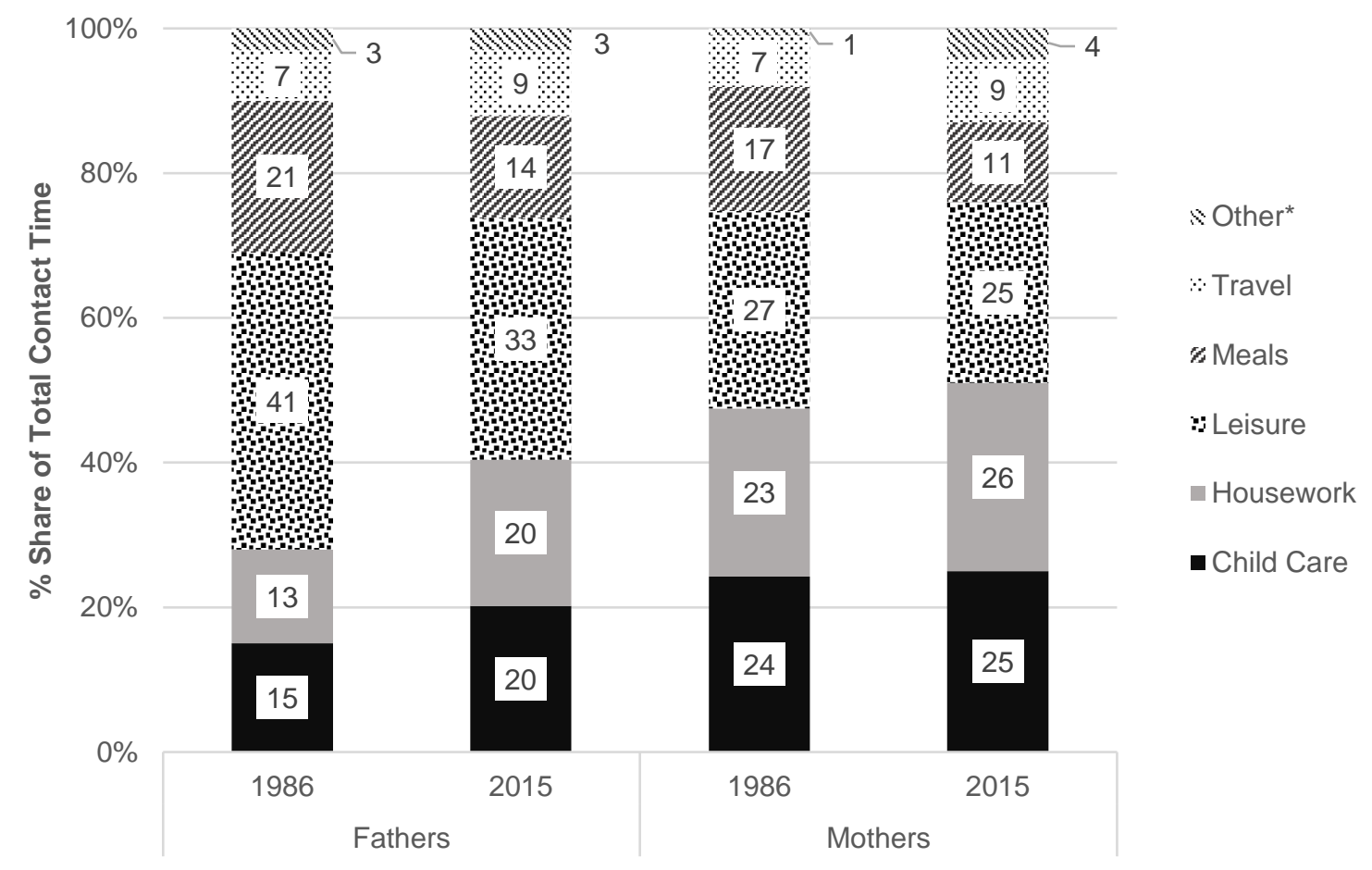

Note: 1986 and 2015 GSS. Total N=5,866. All means weighted with Statistics Canada population weights. * "Other" activities include market work, education, personal care, adult care, and care for nonhousehold children. 


\section{SUPPLEMENTAL APPENDIX}

Table A1: Means and Proportions for Key Variables, Mothers, 1986-2015

\begin{tabular}{|c|c|c|c|c|c|c|}
\hline & 1986 & 1992 & 1998 & 2005 & 2010 & 2015 \\
\hline$N$ & 1,718 & 1,689 & 1,572 & 2,620 & 1,868 & 1,685 \\
\hline Employed & 0.45 & 0.59 & 0.67 & 0.67 & 0.72 & 0.64 \\
\hline Work hours on diary day & 2.72 & 2.45 & 3.16 & 3.28 & 3.07 & 3.41 \\
\hline \multicolumn{7}{|l|}{ Educational attainment } \\
\hline Less than high school & 0.29 & 0.19 & 0.13 & 0.09 & 0.05 & 0.05 \\
\hline High school diploma & 0.43 & 0.42 & 0.38 & 0.31 & 0.22 & 0.14 \\
\hline College diploma & 0.16 & 0.25 & 0.30 & 0.32 & 0.36 & 0.43 \\
\hline University degree & 0.12 & 0.15 & 0.19 & 0.28 & 0.36 & 0.39 \\
\hline \multicolumn{7}{|l|}{ Household income } \\
\hline First quartile & 0.13 & 0.23 & 0.18 & 0.22 & 0.16 & 0.24 \\
\hline Second quartile & 0.27 & 0.16 & 0.24 & 0.19 & 0.27 & 0.13 \\
\hline Third quartile & 0.4 & 0.24 & 0.25 & 0.25 & 0.34 & 0.25 \\
\hline Fourth quartile & 0.11 & 0.2 & 0.15 & 0.17 & 0.13 & 0.38 \\
\hline Missing & 0.1 & 0.18 & 0.17 & 0.16 & 0.12 & 0.00 \\
\hline \multicolumn{7}{|l|}{ Number of household children } \\
\hline One child & 0.46 & 0.30 & 0.45 & 0.47 & 0.44 & 0.47 \\
\hline Two children & 0.54 & 0.70 & 0.55 & 0.53 & 0.56 & 0.53 \\
\hline \multicolumn{7}{|l|}{ Age of youngest household child } \\
\hline $0-4$ years & 0.45 & 0.45 & 0.41 & 0.40 & 0.46 & 0.43 \\
\hline $5-9$ years & 0.29 & 0.29 & 0.31 & 0.30 & 0.28 & 0.27 \\
\hline $10-14$ years & 0.26 & 0.26 & 0.28 & 0.30 & 0.26 & 0.29 \\
\hline \multicolumn{7}{|l|}{ Marital status } \\
\hline Married/Common law & 0.87 & 0.85 & 0.83 & 0.82 & 0.86 & 0.84 \\
\hline Widowed/Separated/Divorced & 0.08 & 0.09 & 0.09 & 0.10 & 0.07 & 0.90 \\
\hline Single & 0.05 & 0.05 & 0.08 & 0.08 & 0.07 & 0.08 \\
\hline Age & 34.06 & 34.15 & 35.91 & 36.86 & 37.00 & 38.45 \\
\hline Immigrant status & 0.21 & 0.18 & 0.19 & 0.22 & 0.25 & 0.31 \\
\hline Quebec & 0.2 & 0.27 & 0.25 & 0.24 & 0.23 & 0.24 \\
\hline$\%$ of activities with kids at home & 73.54 & 67.93 & 67.42 & 63.64 & 71.56 & 71.69 \\
\hline Weekend diary & 0.25 & 0.29 & 0.28 & 0.28 & 0.28 & 0.28 \\
\hline
\end{tabular}

Note: 1986, 1992, 1998, 2005, 2010, 2015 GSS. All means weighted with Statistics Canada population weights. $\mathrm{HH}=$ household. 
Table A2: Means and Proportions for Key Variables, Fathers, 1986-2015

\begin{tabular}{|c|c|c|c|c|c|c|}
\hline & 1986 & 1992 & 1998 & 2005 & 2010 & 2015 \\
\hline$N$ & 1,212 & 1,197 & 1,119 & 1,779 & 1,321 & 1,290 \\
\hline Employed & 0.86 & 0.9 & 0.92 & 0.91 & 0.91 & 0.89 \\
\hline Work hours on diary day & 5.87 & 5.23 & 5.77 & 6.18 & 5.42 & 5.54 \\
\hline \multicolumn{7}{|l|}{ Educational attainment } \\
\hline Less than high school & 0.32 & 0.22 & 0.17 & 0.10 & 0.08 & 0.06 \\
\hline High school diploma & 0.38 & 0.32 & 0.32 & 0.30 & 0.26 & 0.16 \\
\hline College diploma & 0.15 & 0.25 & 0.35 & 0.30 & 0.32 & 0.43 \\
\hline University degree & 0.16 & 0.2 & 0.26 & 0.31 & 0.35 & 0.39 \\
\hline \multicolumn{7}{|l|}{ Household income } \\
\hline First quartile & 0.07 & 0.16 & 0.11 & 0.14 & 0.09 & 0.16 \\
\hline Second quartile & 0.22 & 0.13 & 0.19 & 0.17 & 0.24 & 0.15 \\
\hline Third quartile & 0.49 & 0.28 & 0.29 & 0.30 & 0.29 & 0.26 \\
\hline Fourth quartile & 0.11 & 0.30 & 0.24 & 0.24 & 0.17 & 0.43 \\
\hline Missing & 0.11 & 0.13 & 0.16 & 0.15 & 0.11 & 0.00 \\
\hline \multicolumn{7}{|l|}{ Number of household children } \\
\hline One child & 0.39 & 0.31 & 0.41 & 0.45 & 0.46 & 0.42 \\
\hline Two children & 0.61 & 0.69 & 0.59 & 0.55 & 0.54 & 0.58 \\
\hline \multicolumn{7}{|l|}{ Age of youngest household child } \\
\hline $0-4$ years & 0.47 & 0.50 & 0.45 & 0.4 & 0.46 & 0.44 \\
\hline $5-9$ years & 0.29 & 0.26 & 0.32 & 0.30 & 0.28 & 0.31 \\
\hline $10-14$ years & 0.24 & 0.24 & 0.24 & 0.30 & 0.28 & 0.25 \\
\hline \multicolumn{7}{|l|}{ Marital status } \\
\hline Married/Common law & 0.98 & 0.98 & 0.97 & 0.96 & 0.96 & 0.96 \\
\hline Widowed/Separated/Divorced & 0.01 & 0.02 & 0.02 & 0.03 & 0.02 & 0.03 \\
\hline Single & 0.01 & 0.00 & 0.01 & 0.02 & 0.02 & 0.01 \\
\hline Age & 36.64 & 37.07 & 38.33 & 39.6 & 39.27 & 41.04 \\
\hline Immigrant status & 0.21 & 0.21 & 0.22 & 0.20 & 0.24 & 0.34 \\
\hline Quebec & 0.2 & 0.25 & 0.26 & 0.23 & 0.22 & 0.24 \\
\hline$\%$ of activities with kids at home & 68.1 & 66.38 & 64.74 & 61.63 & 67.59 & 70.61 \\
\hline Weekend diary & 0.21 & 0.28 & 0.32 & 0.27 & 0.31 & 0.30 \\
\hline
\end{tabular}

Note: 1986, 1992, 1998, 2005, 2010, 2015 GSS. All means weighted with Statistics Canada population weights. $\mathrm{HH}=$ household. 
Table A3: OLS Models for Mothers' Total Contact Time with Children and Time Spent in Child Care, 1986 and 2015

\begin{tabular}{|c|c|c|}
\hline & Contact Time & Childcare Time \\
\hline $1986($ ref. $=2015)$ & $\begin{array}{c}-103.76^{* *} \\
(11.23)\end{array}$ & $\begin{array}{c}-41.19 * * \\
(6.19)\end{array}$ \\
\hline Employed & $\begin{array}{l}-12.60 \\
(12.03)\end{array}$ & $\begin{array}{c}-26.74 * * * \\
(6.64)\end{array}$ \\
\hline Paid work hours on diary day & $\begin{array}{c}-29.88 * * * \\
(1.46)\end{array}$ & $\begin{array}{l}-6.08 \\
(0.64)\end{array}$ \\
\hline \multicolumn{3}{|c|}{ Educational attainment (ref. = less than high school) } \\
\hline High school diploma & $\begin{array}{c}-1.52 \\
(13.20)\end{array}$ & $\begin{array}{c}9.72 \\
(6.43)\end{array}$ \\
\hline College diploma & $\begin{array}{l}35.95^{*} \\
(14.73)\end{array}$ & $\begin{array}{l}12.54 \\
(7.49)\end{array}$ \\
\hline University degree & $\begin{array}{l}43.16^{*} \\
(15.85)\end{array}$ & $\begin{array}{l}14.68 \\
(8.40)\end{array}$ \\
\hline \multicolumn{3}{|l|}{ Household income (re. = first quartile) } \\
\hline Second quartile & $\begin{array}{l}-28.37 \\
(15.46)\end{array}$ & $\begin{array}{c}7.74 \\
(7.42)\end{array}$ \\
\hline Third quartile & $\begin{array}{l}-17.87 \\
(15.09)\end{array}$ & $\begin{array}{l}11.90 \\
(7.47)\end{array}$ \\
\hline Fourth quartile & $\begin{array}{l}-33.40 \\
(17.52)\end{array}$ & $\begin{array}{l}20.96 * \\
(10.12)\end{array}$ \\
\hline Missing & $\begin{array}{c}-56.81 * * \\
(21.56)\end{array}$ & $\begin{array}{c}7.72 \\
(10.64)\end{array}$ \\
\hline Two or more HH children (ref. = one child) & $\begin{array}{c}26.53 * * \\
(9.24)\end{array}$ & $\begin{array}{l}11.25^{*} \\
(4.81)\end{array}$ \\
\hline \multicolumn{3}{|l|}{ Age of youngest $\mathrm{HH}$ child (ref. $=0-4$ years old) } \\
\hline $5-9$ years old & $\begin{array}{c}-79.03 * * * \\
(11.37)\end{array}$ & $\begin{array}{c}-54.84 * * * \\
(6.32)\end{array}$ \\
\hline 10-14 years old & $\begin{array}{c}-127.99 * * \\
(14.54)\end{array}$ & $\begin{array}{c}-90.91 * * * \\
(6.45)\end{array}$ \\
\hline \multicolumn{3}{|l|}{ Marital status (ref. $=$ married $/$ common-law) } \\
\hline Widowed/separated/divorced & $\begin{array}{l}-35.97 \\
(18.39)\end{array}$ & $\begin{array}{c}4.73 \\
(8,42)\end{array}$ \\
\hline Single & $\begin{array}{c}-59.06^{* *} \\
(19.04)\end{array}$ & $\begin{array}{l}-10.81 \\
(9.31)\end{array}$ \\
\hline Age (midpoint) of respondent & $\begin{array}{l}-1.91^{*} \\
(0.83)\end{array}$ & $\begin{array}{l}-1.24^{*} \\
(0.38)\end{array}$ \\
\hline Immigrant & $\begin{array}{l}-16.49 \\
(11.43)\end{array}$ & $\begin{array}{c}3.17 \\
(5.82)\end{array}$ \\
\hline Quebec (ref. = other provinces) & $\begin{array}{l}-18.54 \\
(9.78)\end{array}$ & $\begin{array}{l}-6.00 \\
(5.11)\end{array}$ \\
\hline$\%$ of activities at home & $\begin{array}{c}0.67 * * * \\
(0.18)\end{array}$ & $\begin{array}{c}0.63 * * * \\
(0.07)\end{array}$ \\
\hline
\end{tabular}




\begin{tabular}{lcc}
\hline & Contact Time & Childcare Time \\
\hline Weekend diary & $45.28 * * *$ & $-29.90^{* * *}$ \\
& $(11.94)$ & $(5.81)$ \\
Constant & $601.90 * * *$ & $168.92 * * *$ \\
& $(33.92)$ & $(15.87)$ \\
\hline
\end{tabular}

Note: 1986 and 2015 GSS. Total N=3,471. Standard errors in parentheses. Models are weighted with Statistics Canada population weights.

Table A4: OLS Models for Fathers' Total Contact Time with Children and Time Spent in Child Care, 1986 and 2015

\begin{tabular}{|c|c|c|}
\hline & Contact Time & Childcare Time \\
\hline 1986 (ref. $=2015)$ & $\begin{array}{c}-75.39 * * * \\
(12.41)\end{array}$ & $\begin{array}{c}-28.89 * * * \\
(5.03)\end{array}$ \\
\hline Employed & $\begin{array}{c}6.20 \\
(20.75)\end{array}$ & $\begin{array}{c}-17.24 \\
(8.90)\end{array}$ \\
\hline Paid work hours on diary day & $\begin{array}{c}-23.98 * * * \\
(1.69)\end{array}$ & $\begin{array}{c}-3.46^{* * *} \\
(0.53)\end{array}$ \\
\hline \multicolumn{3}{|c|}{ Educational attainment (ref. = less than high school) } \\
\hline High school diploma & $\begin{array}{l}-15.76 \\
(16.02)\end{array}$ & $\begin{array}{c}2.10 \\
(6.06)\end{array}$ \\
\hline College diploma & $\begin{array}{l}-27.28 \\
(17.06)\end{array}$ & $\begin{array}{c}1.73 \\
(6.33)\end{array}$ \\
\hline University degree & $\begin{array}{l}-11.67 \\
(17.50)\end{array}$ & $\begin{array}{l}10.25 \\
(6.97)\end{array}$ \\
\hline \multicolumn{3}{|l|}{ Household income (re. = first quartile) } \\
\hline Second quartile & $\begin{array}{c}2.12 \\
(19.16)\end{array}$ & $\begin{array}{l}16.35 \\
(8.52)\end{array}$ \\
\hline Third quartile & $\begin{array}{c}6.91 \\
(17.21)\end{array}$ & $\begin{array}{l}13.04 \\
(7.16)\end{array}$ \\
\hline Fourth quartile & $\begin{array}{l}-10.84 \\
(18.59)\end{array}$ & $\begin{array}{c}2.27 \\
(6,94)\end{array}$ \\
\hline Missing & $\begin{array}{c}6.82 \\
(44.38)\end{array}$ & $\begin{array}{c}14.27 \\
(13.22)\end{array}$ \\
\hline Two or more HH children (ref. = one child $)$ & $\begin{array}{c}6.95 \\
(11.67)\end{array}$ & $\begin{array}{c}7.29 \\
(4.20)\end{array}$ \\
\hline \multicolumn{3}{|l|}{ Age of youngest $\mathrm{HH}$ child (ref. $=0-4$ years old) } \\
\hline 5-9 years old & $\begin{array}{l}-26.07 * \\
(11.85)\end{array}$ & $\begin{array}{c}-35.82 * * * \\
(5.42)\end{array}$ \\
\hline $10-14$ years old & $\begin{array}{c}-58.12 * * \\
(19.74)\end{array}$ & $\begin{array}{c}-58.94 * * * \\
(6.53)\end{array}$ \\
\hline \multicolumn{3}{|l|}{ Marital status (ref. = married/common-law) } \\
\hline Widowed/separated/divorced & $\begin{array}{c}22.68 \\
(32.37)\end{array}$ & $\begin{array}{c}12.29 \\
(12.50)\end{array}$ \\
\hline Single & $\begin{array}{l}-20.10 \\
(23.48)\end{array}$ & $\begin{array}{c}8.17 \\
(18.11)\end{array}$ \\
\hline
\end{tabular}




\begin{tabular}{lcc}
\hline & Contact Time & Childcare Time \\
\hline Age (midpoint) of respondent & 1.40 & 0.29 \\
& $(1.12)$ & $(0.39)$ \\
Immigrant & $-38.29 * *$ & -8.33 \\
& $(12.89)$ & $(4.89)$ \\
Quebec (ref. = other provinces) & $-23.96^{*}$ & $-9.23^{*}$ \\
& $(10.11)$ & $(4.07)$ \\
\% of activities at home & $0.77^{* * *}$ & $0.32 * * *$ \\
& $(0.15)$ & $(0.05)$ \\
Weekend diary & $105.21^{* * *}$ & -0.44 \\
& $(17.14)$ & $(5.78)$ \\
Constant & $348.35^{* * *}$ & $75.82^{* * *}$ \\
\end{tabular}

Note: 1986 and 2015 GSS. Total $N=2,584$. Standard errors in parentheses. Models are weighted with Statistics Canada population weights. $* \mathrm{p}<0.05$. $* * \mathrm{p}<0.01$. *** $\mathrm{p}<0.001$. 